\title{
Szczególne regulacje prawne samorządu powiatowego w II Rzeczypospolitej
}

\author{
\# samorząd powiatowy \# samorząd terytorialny \# Gdynia \\ \# Warszawa \# autonomia śląska \# II Rzeczypospolita. \\ \# county government \# local government \# Gdynia \\ \# Warsaw \# Silesian Autonomy \# Second Polish Republic
}

Konieczność odbudowy państwowości polskiej, związanej z odzyskaniem w 1918 r. niepodległości, zmusiła władze państwowe do ustanowienia nowego porządku prawnego dotyczącego samorządu terytorialnego. Na terenach II Rzeczypospolitej funkcjonowały dotąd zróżnicowane regulacje prawne dotyczące tej kwestii, konieczne było zatem wprowadzenie przez ustawodawcę w systemie prawnym zmian mających na celu ujednolicenie prawa dotyczącego problematyki samorządowej. Jednakże z perspektywy prawodawcy było to zadanie niezwykle trudne i skomplikowane w związku z tym, że II Rzeczypospolita była państwem różnorodnym ze względu na specyficzne uwarunkowania polityczne, gospodarcze, ekonomiczne, społeczne i historyczne. Podjęte w latach 1918-1939 starania o unifikację obowiązujących przepisów krajowych nie wprowadzały jednakowych zasad z zakresu spraw dotyczących samorządu terytorialnego. Część obszarów państwa zachowała swoją odrębność wobec reszty terytorium II Rzeczypospolitej. Niektóre z tych odmienności miały charakter przejściowy, natomiast inne stały. Do terytoriów o specjalnej charakterystyce ustrojowej w latach 1918-1939 należały: miasto Gdynia, województwo śląskie oraz stolica państwa Warszawa. Odrębność ustrojowa na wyszczególnionych obszarach związana była ze specyfiką tych terenów przez wzgląd na ich sytuację polityczną, społeczną i gospodarczą. W Gdyni i w Warszawie statut oparty był na rozwiązaniach centralistycznych, które ograniczały samorządność, natomiast województwo śląskie cieszyło się szeroką autonomią samorządową.

The necessity to rebuild Polish statehood related to the regaining of independence in 1918 forced state authorities to establish a new legal system concerning local Miasto. Pamięć i Przyszłość 3/2 (2018) ISSN 2543-621X

\section{OPEN ACCESS}

Citation: Raniszewska K., Szczególne regulacje prawne samorządu powiatowego w II Rzeczypospolitej, „Miasto. Pamięć i Przyszłość", 3/2 (2018).

https://doi.org/10.26774/mpp.75

Editor: Jerzy Korczak

Received: October, 2018

Accepted: December, 2018

Published: December, 2018

Copyright: @ Ośrodek „Pamięć i Przyszłośćc This is an open access article distributed under the terms of the Creative Commons Attribution-ShareAlike Licence, which permits unrestricted use, distribution, and reproduction in any medium, provided the original author and source are credited, with indications if any changes are made. All derivative works must be licensed under the same licence. 
self-government. On the territories of the Second Polish Republic there were different legal regulations concerning the issues of local self-government. Therefore, it was necessary for the legislator to introduce changes to the legal system aimed at unifying the law on local government issues. However, from the perspective of the legislator, this task was extremely difficult and complicated due to the fact that the Second Polish Republic was a diverse state due to specific political, economic, economic, social and historical conditions. The efforts undertaken in the years 1918-1939 to unify the existing national laws did not introduce the same rules in matters related to local self-government. Some areas of the country have remained separate from the rest of the territory of the Second Polish Republic. Some of these differences were transient while others were permanent. The territories with special political characteristics in the years 1918-1939 included: the city of Gdynia, the Silesian Voivodeship and the capital of the state Warsaw. The systemic separation in the specified areas was related to the specificity of these areas due to their political, social and economic situation. In Gdynia and Warsaw, the statute is based on centralist solutions that limited self-government. The Silesian Voivodeship, on the other hand, enjoyed wide self-government.

Kamila Raniszewska - studentka stacjonarnych studiów na kierunku administracja na Wydziale Prawa, Administracji i Ekonomii Uniwersytetu Wrocławskiego, przewodniczaca Koła Naukowego Historii Państwa i Prawa. 


\section{Wprowadzenie}

W momencie powstania II Rzeczypospolitej istniał na ziemiach byłych zaborów samorząd terytorialny, różny jednakże był zakres jego działania i różna struktura organów samorządowych?. Większość wysiłków skierowano na zunifikowanie administracji oraz zacieranie „pozostałości po zaborczych systemach organizacyjnych i prawnych"². Niezbędnym oraz skomplikowanym zadaniem było unormowanie samorządu terytorialnego, gdyż na terenie II Rzeczypospolitej istniało różnorodne ustawodawstwo (m.in. pruskie, austriackie, rosyjskie, francuskie, węgierskie). Na rozwój i przekształcanie się samorządu wpływ miały siły społeczne, polityczne i ekonomiczne, a nie prawo.

Odrębności ustroju samorządowego możemy podzielić na takie, które istniały przez cały okres II Rzeczypospolitej oraz takie, które miały charakter jedynie przejściowy. Do tych pierwszych zaliczamy miasto Gdynię, autonomiczne województwo śląskie oraz miasto stołeczne Warszawę, do drugich natomiast - Litwę Środkową

Miasto. Pamięć i Przyszłość 3/2 (2018) ISSN 2543-621X
(1920-1922)3, obszar Spisza i Orawy (1920-1925)4, a także miasta Kraków i Lwów (1918-1933)5.

\section{Miasto Gdynia}

Traktat pokojowy został podpisany w Wersalu dnia 28 czerwca 1919 roku$^{6}$. Na podstawie dokumentu Rzeczypospolita Polska zyskała część obszaru Pomorza, jednakże z wyłączeniem Gdańska (z przyległymi gminami i miastami Oliwą i Sopotem), który stał się Wolnym Miastem o charakterze odrębnego państwa pod protektoratem Ligi Narodów?

Po odzyskaniu przez Polskę niepodległości ustrój Gdyni oparto na obowiązującej na tym terenie pruskiej ordynacji gminnej z dnia

1. J. Senkowski, Administracja i samorzad w Polsce w latach 1918 1939, cz. 1-3. [B.m.], [b.w.], [1970].

2. J. Służewski, Wojewoda w systemie administracji państwowej, Warszawa 1981, s. 8.

3. Por. B. Kotlarz, Administracja terytorialna i samorzad na terenie Litwy Środkowej w latach 1920-1922, "Gdańskie Studia Prawnicze” 2005, t. XIV, s. 105-116.

4. Por. J. Ciągwa, Stan prawny na Spiszu i Orawie w latach międzywojennych, Prace Naukowe UŚl. Nr 782, „Studia Iuridica Silesies” 1986, t. 11, s. 120-151.

5. Ustrój Lwowa oparty był na ustawie krajowej z 1870 r., natomiast ustrój Krakowa na ustawie krajowej z 1867.

6. Dz.U. RP z 1920 r. Nr 35, poz. 200.

7. Por. art. 100-108 Traktatu Wersalskiego. 
3 lipca 1891 roku. Podział organów ze względu na kompetencje i zadania wyglądał następująco: organem uchwałodawczym i kontrolującym była rada gminna, a organem wykonawczym - zarząd gminy, w skład, którego wchodził sołtys oraz ławnicy wybrani przez radę gminną i zatwierdzani przez starostę.

Rada Ministrów na podstawie rozporządzenia z 10 lutego 1926 r. wydała zezwolenie gminie wiejskiej Gdynia w powiecie wejherowskim w województwie pomorskim na przyjęcie ustroju według pruskiej ordynacji miejskiej9. Wprowadzona zmiana spowodowała powołanie z dniem 10 kwietnia 1926 r. tymczasowej rady miejskiej składającej się z 12 osób. Utworzono także magistrat pełniący funkcje wykonawcze, który składał się z komisarycznego burmistrza oraz dwóch członków. Głównym zadaniem powołanych organów było przygotowanie i przeprowadzenie wyborów samorządowych (odbyły się pod koniec 1926 r.). Wyłoniono w nich 12 osobową radę miejską, której kadencja miała trwać 4 lata oraz burmistrza wybranego na 12 lat.

Na podstawie postanowienia Ministra Spraw Wewnętrznych z dnia 9 czerwca 1926 r. zarządzono utworzenie urzędu policyjnego w Gdyni. Kierownictwo tego urzędu zostało powierzone urzędnikowi, wyznaczonemu przez wojewodę pomorskiego. Terytorialny zakres działania państwowego urzędu policyjnego obejmował tereny gminy Gdynia, zaś zakres rzeczowy - wydzielone

8. L. Bar, Samorzą terytorialny w // Rzeczypospolitej, „Rada Narodowa-Gospodarka-Administracja" 1978, R. 6, nr 20, s. 40.

9. Dz.U. z 1926 r. Nr 21, poz. 127.

10. Postanowienie MSW z 9 czerwca 1926 r. w sprawie utworzenia urzędu policyjnego w Gdyni (M.P. Nr. 134, poz. 387).

11. Postanowienie MSW wydane w porozumieniu z MRP z dnia 30 maja 1928 r. (M.P. Nr. 132, poz. 224). z kompetencji miejscowej i władzy policyjnej (burmistrza) agendy policji bezpieczeństwa oraz policji zdrowia i policji weterynaryjnej.

W szczególności do kompetencji państwowego urzędu policyjnego należały sprawy:

1) utrzymania bezpieczeństwa, spokoju i porządku publicznego w miejscach użyteczności publicznej, łącznie ze służbą nocną oraz ustalenie godziny policyjnej;

2) z zakresu policji politycznej stowarzyszeń i zgromadzeń, cenzury teatralnej i kinematograficznej;

3) z zakresu policji kryminalnej i obyczajowej;

4) związane ze zwalczaniem chorób zakaźnych i zaraz zwierzęcych.

Zorganizowanie i uruchomienie państwowego urzędu policyjnego w Gdyni powierzono wojewodzie pomorskiemu ${ }^{10}$, natomiast dnia 30 maja 1928 r. na mocy postanowienia Ministra Spraw Wewnętrznych zakres działania państwowego urzędu policyjnego został poszerzony o sprawy policji budowlanej"1.

Rozporządzeniem Rady Ministrów z dnia 30 grudnia 1925 r. przyłączono do gminy Gdyni ChyIonię znajdującą się w powiecie wejherowskim oraz gminę Oksywie znajdującą się w powiecie puckim. Dzięki temu cała Gdynia wraz z obszarem budowy portu znajdowała się w obrębie jednego powiatu.

W listopadzie 1926 r. na mocy rozporządzenia Prezydenta RP został utworzony powiat morski, w skład którego wchodziło miasto Gdynia, mające pełnić funkcję siedziby starosty, jednak z powodów logistycznych nie udało się

Miasto. Pamięć i Przyszłość 3/2 (2018) ISSN 2543-621X 
tego zrealizowaćn ${ }^{12}$. Na początku istnienia powiatu morskiego siedzibą starostwa był Puck, a następnie - Wejherowo. Na podstawie rozporządzenia Rady Ministrów z dnia 11 stycznia 1929 r. gmina miejska Gdynia została wydzielona z powiatu morskiego i został stworzony z niej odrębny powiat miejski dla celów administracji państwowej i samorządowej³. Jednocześnie rozporządzenie to zlikwidowało państwowy urząd policyjny, którego zadania przydzielono powołanemu staroście grodzkiemu.

W związku z nieudolnością administracji gdyńskiej oraz konsekwencją nasilenia problemów ze sprawowaniem władzy, dalsze funkcjonowanie samorządu na zasadach ogólnych okazało się niewystarczające, postanowiono więc wprowadzić nowe regulacje prawne dotyczące ustroju miasta Gdyni. Na podstawie rozporządzenia Prezydenta RP z dnia 24 listopada 1930 r. na czele powiatu miejskiego w Gdyni stać miał Komisarz Rządu mianowany z ramienia Ministra Spraw Wewnętrznych w porozumieniu z Ministrem Przemysłu i Handlu oraz Ministrem Skarbu. Komisarz Rządu łączył zakresem swych kompetencji działania burmistrza, magistratu, przewodniczącego rady miejskiej oraz starosty grodzkiego. Nadto pełnił funkcje przedstawiciela rządu w powiecie miejskim oraz był zwierzchnikiem podporządkowanych mu urzędów i organów, a także ich przełożonym. Wykonywał zadania zlecone przez wojewodę pomorskiego oraz poszczególnych ministrów. Ustanowiono również jego zastępcę mianowanego przez tych samych trzech ministrów.

Miasto. Pamięći Przyszłość 3/2 (2018) ISSN 2543-621X
Poszczególni ministrowie działów administracji zespolonych z administracją ogólną upoważnieni byli do przekazywania kompetencji wojewodzie pomorskiemu w sprawach dotyczących powiatu miejskiego w Gdyni, które zastrzeżone były dla Komisarza Rządu4.

Rozporządzenie wprowadziło również określoną hierarchię pomiędzy władzami rządowymi. Ministrowie odnośnie do zadań, co do których byli kompetentni i właściwi, zostali zobowiązani do przekazywania ich wojewodzie pomorskiemu lub bezpośrednio Komisarzowi, natomiast wojewoda pomorski przekazywał zadania zlecone Komisarzowi Rządu. Zgodnie z rozporządzeniem obowiązywała również zasada podległości zarówno osobowej, jak i służbowej Komisarza Rządu. Osobowo oraz służbowo w zakresie administracji ogólnej i w działach z nią zespolonych Komisarz Rządu podlegał wojewodzie pomorskiemu, zaś w sprawach z zakresu administracji państwowej podlegał służbowo poszczególnym ministrom ${ }^{15}$.

Komisarz Rządu stał na czele Komisariatu Rządu, określał także kierunki działalności oraz sprawował kontrolę nad tym urzędem. Jako przewodniczącemu rady miejskiej Komisarzowi przysługiwały następujące kompetencje ${ }^{16}$ :

ustalenie porządku obrad;

zwoływanie posiedzeń rady i kierowanie nimi;

przestrzeganie regulaminu obrad;

12. Dz.U. RP Nr 117, poz. 678.

13. Dz. U. RP Nr 4, poz. 35.

14. Dz.U. $1930 \mathrm{nr}$ 80, poz. 630.

15. K. W. Kumaniecki, J. Langrod, S. Wachholz, Zarys ustroju, postępowania i prawa administracyjnego w Polsce, Kraków 1939, s. 91. 16. M. Widernik, Główne problemy gospodarczo-społeczne miasta Gdyni w latach 1926-1939, Gdańsk 1970, s. 4. 
- $\quad$ przyjmowanie i załatwianie korespondencji; - czuwanie nad wykonywaniem uchwał rady; - $\quad$ udział w komisjach powoływanych przez radę z prawem głosu;

zawieszanie uchwał rady, a także odmowy wykonania uchwał w przypadku, gdy uznał je za niecelowe.

Zmianie miało ulec funkcjonowanie rady miejskiej. Zdecydowano, że z dniem ogłoszenia rozporządzenia dotychczas funkcjonująca rada miała zostać rozwiązana. Kadencja wcześniej funkcjonującej rady trwała do 1933 r. natomiast od marca 1933 r., zgodnie z rozporządzeniem, rada miejska miała składać się z 20 członków. Połowę tej liczby stanowiły osoby mianowane przez Ministra Spraw Wewnętrznych w porozumieniu z Ministrem Przemysłu i Handlu, a druga połowa miała zostać wyłoniona na podstawie wyborów zgodnie z panującymi w tamtym czasie przepisami prawa17.

Zaprezentowany powyżej ustrój Gdyni, wprowadzony na podstawie rozporządzenia Prezydenta z 1930 r., został ustanowiony na okres przejściowy wynoszący 5 lat. Po upływie tego terminu, zgodnie z art. 10 ust. 2 powyższego aktu, Rada Ministrów wydała rozporządzenie o przedłużeniu rozwiązań komisarycznych na dalsze 3 lata ${ }^{18}$.

Na podstawie ustawy z dnia 28 marca $1938 \mathrm{r}$. dokonano zmiany rozporządzenia Prezydenta RP dotyczącego miasta Gdyni. Rozszerzono

17. B. Wasiutyński, Ustrój władz administracyjnych, rządowych i samorzadowych, Poznań 1937, s. 95.

18. M. Makuch, Szczególne regulacje prawne ustroju samorzadowego w II RP (status miasta Gdyni, samorzadu śląskiego i miasta stołecznego Warszawy), [w:] 20 lat samorzadu terytorialnego w II i III Rzeczypospolitej, red. J. Korczak, Wrocław 2010, s. 34.

19. Ustawa z dnia 28 marca o zmianie rozporządzenia Prezydenta Rzeczypospolitej o ustroju miasta Gdyni (Dz. U. RP Nr 22, poz. 190) zakres kompetencji Komisarza Rządu w Gdyni, któremu nadano kompetencje prawne i obowiązki przełożonego gminy oraz starosty grodzkiego. Na mocy ustawy po jej wprowadzeniu rada miejska w Gdyni składać miała się z 48 członków, z których 32 pochodziło z wyborów, 16 zaś mianował i odwoływał Minister Spraw Wewnętrznych w porozumieniu z Ministrem Przemysłu i Handlu. Wybory do nowej rady miejskiej miały zostać zarządzone z chwilą wejścia w życie ustawy, a dotychczasowa rada miejska miała przestać urzędować z chwilą wyboru nowej rady miejskiej. W zgodzie z nowymi zasadami ustawy zarząd miejski składać się miał z Komisarza Rządu, jego zastępcy oraz 5 ławników z wyboru. Komisarzowi Rządu i jego zastępcy przysługiwać również miały środki z funduszów gminy miejskiej Gdyni, czyli dodatki pieniężne w wysokości określonej przez Ministra Spraw Wewnętrznych w porozumieniu z Ministrem Skarbu. W ten sposób wprowadzony ustrój z dnia 28 marca 1938 r. miał obowiązywać do dnia 29 listopada 1943 r.19.

Ustrój komisaryczny zastosowany wobec miasta Gdyni w znacznym zakresie ograniczał samorząd miejski na rzecz administracji państwowej. Z pewnością wprowadzenie takich rozwiązań związane było z koncepcją centralistycznego zarządzania miastem. Kompetencje przekazane przez państwo polskie Komisarzowi były bardzo rozległe i umożliwiały skupienie władzy w "jednej ręce”, co stworzyło możliwość szybkiej budowy i rozwoju miasta, a także bezproblemową realizację założeń polityki państwa

Miasto. Pamięć i Przyszłość 3/2 (2018) ISSN 2543-621X 
na obszarze Gdyni. Powyższe rozwiązania ustrojowe funkcjonowały na obszarze miasta Gdyni od 1930 r. aż do 1939 r. ${ }^{20}$.

\section{Autonomiczne województwo śląskie}

Województwo śląskie swoją autonomię uzyskało na podstawie ustawy konstytucyjnej Sejmu Ustawodawczego Rzeczypospolitej Polskiej z dnia 15 lipca 1920 r. Wspomniany akt prawny zawierał statut organiczny województwa śląskiego. Obejmowało ono swym obszarem ziemie Górnego Śląska oraz Śląska Cieszyńskiego, natomiast pod koniec lat 30. XX w. w jego skład wchodziły również zaanektowane tereny Zaolzia (od października 1938 r.) oraz część ziem z powiatu frydeckiego oraz z Ziemi Czadeckiej (od listopada 1938 r.) $)^{21}$.

W górnośląskiej części województwa samorząd powiatowy postanowiono uregulować na podstawie pruskiej ustawy o ustroju powiatów z 13 grudnia 1872 r. Rozporządzeniem z dnia 17 czerwca 1922 r. w przedmiocie ustroju powiatowego województwa śląskiego usunięto pochodzące z wyboru wydziały powiatowe oraz sejmik, a na ich miejsce powołano komisaryczne wydziały powiatowe mianowane z ramienia wojewody. Aktem prawnym z dnia 27 lutego 1924 r. utworzono również komisaryczne wydziały dróg powiatowych w Cieszynie oraz Bielsku. Wydział stanowili starosta jako przewodniczący oraz sześciu członków mianowanych przez wojewodę. Województwo śląskie składało się z 7 powiatów. W części górnośląskiej były to powiaty: katowicki, lubliniecki, pszczyński, rybnicki,

Miasto. Pamięć i Przyszłość 3/2 (2018) ISSN 2543-621X rudzki (zniesiony dnia 7 marca 1939 r.) i tarnogórski. Część cieszyńską stanowiły dwa powiaty - bielski i cieszyński, których to na podstawie ustawy obszar poszerzono o ziemie powiatów frydeckiego i czadeckiego. Warto wspomnieć, że Katowice i Królewska Huta (Chorzów) były miastami wydzielonymi.

Powyższy stan prawny autonomicznego województwa śląskiego funkcjonował do wybuchu Il wojny światowej. Formalnie zlikwidowano autonomię na mocy Ustawy Konstytucyjnej z dnia 6 maja 1945 r. o zniesieniu statutu organicznego województwa śląskiego.

\section{Miasto stołeczne Warszawa}

Ustrój Warszawy w pierwszych latach istnienia II RP funkcjonował na zasadach ogólnych właściwych dla gmin miejskich byłego Królestwa Kongresowego. Dnia 13 grudnia 1918 r. wydano dekret o wyborach do rad miejskich na terenie byłego Królestwa Kongresowego, który zmienił funkcjonowanie miasta na szczeblu samorządowym²2.

W Warszawie w skład rady miejskiej miało wchodzić 120 radnych, a całe miasto stanowiło jeden okręg wyborczy. Dla uzupełnienia liczby radnych, w razie ich śmierci oraz w razie złożenia lub utracenia przez nich mandatów, wybierani byli zastępcy radnych w liczbie wynoszącej połowę liczby radnych. Czynne prawo wyborcze do rad miejskich posiadali wszyscy obywatele bez względu na płeć, ale musieli spełniać następujące przesłanki: mieć ukończone 21 lat, posiadać polską przynależność państwową

20. M. Makuch, dz. cyt., s. 35.

21. K. W. Kumaniecki, J. Langrod, S. Wachholz, dz. cyt., s. 96. 22. M. Makuch, dz. cyt., s. 44. 
i mieszkać w obrębie gminy miejskiej co najmniej od 6 miesięcy. Bierne prawo wyborcze posiadały natomiast osoby mające czynne prawo wyborcze, ukończone 25 lat i umiejące czytać i pisać po polsku. Członkami rady miejskiej nie mogli być płatni urzędnicy miejscy oraz urzędnicy państwowi, którzy sprawowali nadzór nad działalnością gminy miejskiej, wliczając w to funkcjonariuszy policji i milicji ludowej23.

Następne zmiany w ustroju samorządowym miasta Warszawy poczyniono na zasadach zawartych w dekrecie z dnia 4 lutego 1919 r. o samorządzie miejskim. Rada miejska była przedstawicielką gminy, a w sprawach należących do zakresu działania gminy, rada miejska była organem uchwałodawczym i kontrolującym. Członkami rady miejskiej byli radni i członkowie magistratu. Liczbę radnych w poszczególnych miastach określał dekret o wyborach do rad miejskich na terenie byłego Królestwa Kongresowego z dnia 13 grudnia 1918 r. (w Warszawie 120 radnych), a ich kadencja trwała 3 lata. Obradom rady miejskiej przewodniczył prezydent miasta. Władzę wykonawczą i zarządzającą sprawował magistrat. Dekret stanowił, że w skład magistratu wchodzili prezydent, trzej wiceprezydenci i ławnicy w liczbie 12 (liczba ławników wynosiła w każdym mieście 10\% liczby radnych). Członków magistratu wybierano na kadencję trwającą 3 lata lub względnie do końca kadencji rady miejskiej. Głosowanie na ławników odbywało się na zasadach proporcjonalności. Bliższe przepisy o wyborach określał specjalny

23. Dz.Pr.K.P. Nr 20, poz. 58.

24. Dz.Pr.P.P. Nr 13, poz. 140.

25. M. Jaroszyński, Problem ustroju stolicy, Warszawa 1934, s. 8-9.

26. Dz.Pr. P.P. Nr 1, poz. 79. regulamin, wydany przez Ministra Spraw Wewnętrznych. Prezydent i jego zastępcy wybierani byli absolutną większością głosów. Warto zaznaczyć, że prezydent - oprócz obowiązku polskiej przynależności państwowej i biernego prawa wyborczego do rad miejskich - musiał posiadać również wykształcenie w zakresie co najmniej polskiej szkoły ludowej. Co do zasady działanie magistratu oparte było na kolegialnym systemie sprawowania urzędu²4.

Do zadań magistratu Warszawy należało przedstawianie obrachunków miejskich radzie miasta w terminie 6 miesięcy po zakończeniu roku budżetowego. Rada Miejska miasta stołecznego Warszawy mogła zostać rozwiązana tylko decyzją Prezydenta RP. Tylko Prezydent RP posiadał kompetencje do odwołania prezydenta Warszawy i jego zastępców. W pozostałym zakresie samorząd warszawski oparty był na takich samych zasadach, co reszta gmin objętych wspomnianym wyżej dekretem²5.

Dekretem z dnia 2 stycznia 1919 r. o wprowadzeniu stanu wyjątkowego Rada Ministrów, na wniosek Ministra Spraw Wewnętrznych, mogła wprowadzić na czas nie dłuższy niż trzy miesiące stan wyjątkowy w każdej miejscowości, w której ze względu na bezpieczeństwo publiczne zastosowanie tego środka okazało się konieczne. Z chwilą ogłoszenia stanu wyjątkowego, Ministrowi Spraw Wewnętrznych lub wyznaczonemu przez niego nadzwyczajnemu komisarzowi przysługiwał szereg dodatkowych kompetencji26. W przypadku Warszawy na tę ewentualność powstał urząd Nadzwyczajnego

Miasto. Pamięć i Przyszłość 3/2 (2018) ISSN 2543-621X 
Komisarza miasta stołecznego Warszawy i powiatu warszawskiego ${ }^{27}$. Do jego kompetencji należało prawo do 28 :

wydawania nadzwyczajnych rozporządzeń obowiązujących w przedmiocie utrzymania bezpieczeństwa publicznego;

- wymierzania za przekroczenie tych rozporządzeń kary trzech miesięcy więzienia lub do trzech tysięcy marek grzywny z możliwością zamiany grzywny na areszt do trzech miesięcy w razie niewypłacalności;

- zakazywania wieców, zebrań i zgromadzeń publicznych oraz pochodów publicznych, a w razie sprzeciwienia się zakazowi rozpraszania ich siłą zbrojną;

- zarządzania rewizji, gdy zajdzie taka potrzeba oraz internowania czasowego osób, których działalność zagraża bezpieczeństwu i spokojowi publicznemu;

- zarządzania konfiskaty wszelkich wydawnictw zagrażających bezpieczeństwu publicznemu i zamykania na czas trwania stanu wyjątkowego drukarni służących do ich rozpowszechniania.

Na podstawie ustawy z dnia 2 sierpnia 1919 r. o organizacji władz administracyjnych II instancji Warszawa - do czasu wejścia w życie ustawy o ustroju administracyjnym Rzeczypospolitej Polskiej - stała się województwem i stanowiła odrębną jednostkę administracyjną. Powyższy akt prawny nie sprecyzował, jak powinna wyglądać organizacja administracji publicznej na terenie Warszawy oraz nie powoływał właściwego organu do sprawowania władzy na jej obszarze ${ }^{29}$.

Miasto. Pamięć i Przyszłość 3/2 (2018) ISSN 2543-621X
Po odwołaniu stanu nadzwyczajnego urząd Komisarza Rządu w Warszawie nadal funkcjonował i oparty był na uregulowaniach prawnych wynikających z ustawy w przedmiocie zapewnienia bezpieczeństwa państwa i utrzymania porządku publicznego w czasie wojny ${ }^{30}$ z dnia 25 lipca 1919 r. Organem Komisarza Rządu był Komisariat Rządu, który podzielono na wydziały zarządzane przez naczelników. Funkcjonowało pięć wydziałów:

1) spraw osobowych, finansowych i gospodarczych;

2) ogólno-administracyjny;

3) administracyjno-prawny;

4) meldunkowy i rejestracji cudzoziemców;

5) prasowo-widowiskowy.

Na podstawie rozporządzenia Rady Ministrów z dnia 23 lutego 1920 r. w przedmiocie tymczasowej organizacji władzy administracyjnej w I instancji w miastach Warszawie, Łodzi i Lublinie, Komisariat Rządu stał się władzą administracyjną w I instancji, której decyzje podlegały pod urząd Ministra Spraw Wewnętrznych ${ }^{31}$. W praktyce jednak Komisariat pełnił zadania zarówno I, jak i II instancji32. W latach 1919-1928 kompetencje Komisarza Rządu uległy poszerzeniu ze względu na fakt przekazania na rzecz Komisarza różnych kompetencji aktami podustawowymi. W związku z tym Komisarz Rządu posiadał odtąd uprawnienia dorównujące

27. Rozporządzenie MSW w przedmiocie mianowania Nadzwyczajnego Komisarza st. m. Warszawy i powiatu warszawskiego (Dz. Urz. MSW 1919 Nr 3).

28. Dz.Pr. P.P. Nr 1, poz. 79.

29. Dz.Pr.P.P. Nr 65, poz. 395.

30. Dz.Pr.P.P. Nr 61, poz. 364

31. Dz.U. RP Nr 20, poz. 106.

32. M. Makuch, dz. cyt., s. 45. 
zakresem urzędowi wojewody. W odniesieniu do samorządu Warszawy Komisarz prowadził kontrolę nad wykonywanymi przez gminę zadaniami zleconymi33.

Przełomowym momentem w sprawie administracji rządowej w Warszawie było wydanie przez Radę Ministrów rozporządzenia z dnia 5 lipca 1928 r. o organizacji i zakresie działania władz administracji ogólnej na obszarze miasta stołecznego Warszawy. Był to zarazem pierwszy akt prawny, który w całości swoją treścią odnosił się do administracji rządowej na terenie Warszawy. Zgodnie z jego postanowieniami dla celów administracji ogólnej Warszawa podzielona została na trzy powiaty grodzkie: Warszawę Północ, Warszawę Południe oraz Warszawę Pragę34.

Zarząd nad utworzonymi powiatami sprawowali starostowie grodzcy, którzy powoływani byli z ramienia Ministra Spraw Wewnętrznych. Poza nazwą urzędu zakres ich kompetencji nie różnił się od zakresu działania starostów powiatowych ${ }^{35}$. Służbowo starostowie grodzcy za swoją działalność ponosili odpowiedzialność przed Komisarzem Rządu, natomiast pod względem odpowiedzialności osobowej na podstawie przepisów o służbie cywilnej podlegali Komisarzowi Rządu lub Ministrowi Spraw Wewnętrznych.

33. J. Kowalczewski, Administracja rządowa na obszarze m. st. Warszawy, "Gazeta Administracji” 1936, R. 18, nr 10, s. 390.

34. Dz. U. RP Nr 72, poz. 647. Rozporządzenie to zostało wydane na podstawie rozporządzenia Prezydenta RP z dnia 19 stycznia 1928 r. o organizacji i zakresie działania władz administracji ogólnej (Dz. U. RP Nr 11, poz. 86).

35. B. Wasiutyński, dz. cyt., s. 46 i 64.

36. M. Makuch, dz. cyt., s. 46-47.

37. Ustawa z dnia 23 marca 1933 r. o częściowej zmianie ustroju samorządu terytorialnego (Dz.U. 1933 Nr 35, poz. 294).
Na podstawie całości powyższych rozważań można zauważyć, że miasto Warszawa posiadała cechy gminy jednostkowej, jak również powiatu miejskiego oraz osobnego województwa nienależącego do przylegającego obszaru województwa warszawskiego. Na terenie Warszawy funkcjonowały organy komunalne, rządowe organy administracji ogólnej zarówno na stopniu powiatowym (starostwa), jak i wojewódzkim (Komisariat Rządu), a także inne organy rządowe niezespolone z administracją ogólną. Uwidacznia się w tym momencie funkcjonowanie władz samorządowych oraz rządowych, które określane były mianem tzw. dwutorowości36.

Następne zmiany w zakresie samorządowego ustroju Warszawy przypadły na 1933 r. W związku z uchwaleniem ustawy dnia 23 marca 1933 r. o częściowej zmianie ustroju samorządowego, tzw. ustawy scaleniowej, wprowadzono niewielkie zmiany, które jednak nie wprowadzały odrębnych rozwiązań prawnych charakterystycznych wyłącznie dla Warszawy, a jedynie pewne odstępstwa od reguł ogólnokrajowych. Do wspomnianych odstępstw należały ${ }^{37}$ :

1) W warszawskiej radzie miejskiej zasiadać miało 100 radnych;

2) maksymalna liczba wiceprezydentów nie mogła przekroczyć 5;

3) Komisarz Rządu miał nadzorować działania prezydenta Warszawy w sprawach administracji ogólnej;

4) zatwierdzenie wyboru nowego prezydenta Warszawy przez Radę Ministrów;

Miasto. Pamięć i Przyszłość 3/2 (2018) ISSN 2543-621X 
5) Prezydent RP $w$ terminie 3 lat od wejścia w życie wyżej wymienionej ustawy posiadał prawo wydania statutu ustroju miasta w formie rozporządzenia z mocą ustawy;

6) brak możliwości wchodzenia w struktury organów gminy miasta stołecznego Warszawy pracowników Ministerstwa Spraw Wewnętrznych;

7) rozpatrywanie przez Ministra Spraw Wewnętrznych wniesionych zgodnie z prawem zażaleń i protestów wyborczych przeciw wyborom do rady miejskiej lub zarządu;

8) możliwość rozwiązania przez Radę Ministrów na wniosek Ministra Spraw Wewnętrznych organu stanowiącego i zarządzającego przy zaistnieniu wymaganych przesłanek. W myśl regulacji ogólnokrajowych kompetencje magistratu przejął zarząd miejski. W marcu 1934 r. zgodnie z przepisami powyższego aktu prawnego rozwiązana została warszawska rada miejska.

Na podstawie rozporządzenia Prezydenta RP z dnia 24 września 1934 r., które w całości odnosiło się do miasta Warszawy, zdecydowano, że w miejsce rady miejskiej powołany zostanie tymczasowy zarząd miejski, który przejmie obowiązki po poprzednim organie. Nowo powołany organ miał składać się z prezydenta Warszawy oraz pięciu wiceprezydentów. Rada Ministrów na wniosek Ministra Spraw Wewnętrznych posiadała kompetencje do powołania prezydenta, a wiceprezydentów powoływał sam Minister Spraw Wewnętrznych. W sytuacji, kiedy zarząd działał kolegialnie albo jednoosobowo poprzez

Miasto. Pamięći Przyszłość 3/2 (2018) ISSN 2543-621X 25 prezydenta miasta, przysługiwały mu odpowiednio uprawnienia rady miejskiej. Rolę organu opiniodawczego w myśl zasad zawartych w rozporządzeniu sprawować miała rada miejska złożona z 36 członków powoływanych przez Ministra Spraw Wewnętrznych. Nowo powołanym organem była również komisja rewizyjna, do której zakresu działań należało sprawowanie kontroli wewnętrznej zgodnie z zasadami ustawy samorządowej z 1933 r. Ponadto należy wspomnieć, że komisja była organem niezależnym i uprawnionym do składania sprawozdań władzy nadzorczej ${ }^{38}$. Powyższe ustalenia prawne miały obowiązywać czasowo, nie dłużej niż do dnia 31 marca 1936 r., okres ten został jednak przedłużony do 1 października 1938 r. na mocy ustaw z $1936^{39}$ oraz 1937 r.40.

Ostatnimi aktami prawnymi, o których warto wspomnieć w kontekście miasta Warszawy w okresie międzywojennym, były ustawy z dnia 16 sierpnia 1938 r. o samorządzie gminy miasta stołecznego Warszawy oraz o wyborze radnych miejskich. Warszawa po uchwaleniu powyższych aktów prawnych stała się jednostką samorządu terytorialnego, gminnego, powiatowego i wojewódzkiego oraz posiadała osobowość publiczno-prawną ${ }^{41}$. Zastosowane rozwiązania przystosowały ustrój miasta do specyfiki Warszawy jako stolicy państwa.

W związku z podjętymi przez prawodawcę działaniami, mającymi na celu unifikację prawa

38. Dz. U. RP Nr 86, poz. 778.

39. Ustawa z dnia 30 marca 1936 roku o przedłużeniu okresu urzędowania tymczasowych organów ustrojowych gminy miasta stołecznego Warszawy (Dz.U. RP Nr 23, poz. 188).

40. Ustawa z dnia 22 czerwca 1937 roku o przedłużeniu okresu urzędowania tymczasowych organów ustrojowych gminy miasta stołecznego Warszawy (Dz.U. RP Nr 48, poz. 371).

41. Dz.U. RP Nr 63, poz. 479 i Dz.U. RP Nr 63, poz. 480. 
dotyczącego samorządu terytorialnego na niektórych terenach państwa, wyodrębnić można różne regulacje ustrojowe dotyczące samorządu terytorialnego. Funkcjonowały one ze względu na szczególne znaczenie dla rozwoju państwa. Status prawny Gdyni i Warszawy oparty został na rozwiązaniach centralistycznych, które ograniczały samorządność, zaś województwo śląskie cieszyło się w tym samym czasie, tj. w okresie II RP, szeroką autonomią i swobodą.

\section{Literatura:}

- L. Bar, Samorzad terytorialny w II Rzeczypospolitej, „Rada Narodowa-Gospodarka-Administracja”, 1978, R. 6, nr 20.

- J. Ciągwa, Stan prawny na Spiszu i Orawie w latach międzywojennych, Prace Naukowe UŚl. Nr 782, "Studia Iuridica Silesies" 1986, t. 11.

- M. Jaroszyński, Problem ustroju stolicy, Warszawa 1934.

- B. Kotlarz, Administracja terytorialna i samorzad na terenie Litwy Środkowej w latach 1920-1922, „Gdańskie Studia Prawnicze" 2005, t. XIV.

- J. Kowalczewski, Administracja rzqdowa na obszarze m. st. Warszawy, "Gazeta Administracji” 1936, R. 18, nr 10.

- K. W. Kumaniecki, J. Langrod, S. Wachholz, Zarys ustroju, postępowania i prawa administracyjnego w Polsce, Kraków 1939.

- M. Makuch, Szczególne regulacje prawne ustroju samorzadowego w II RP (status miasta Gdyni, samorządu śląskiego i miasta stołecznego Warszawy), [w:] 20 lat samorzadu terytorialnego w II i III Rzeczypospolitej, red. J. Korczak, Wrocław 2010.

- J. Senkowski, Administracja i samorzad w Polsce w latach 1918-1939, cz. 1-3, [B.m.], [b.w.], [1970].

- J. Służewski, Wojewoda w systemie administracji państwowej, Warszawa 1981.

- M. Widernik, Główne problemy gospodarczo-społeczne miasta Gdyni w latach 1926-1939, Gdańsk 1970.

- B. Wasiutyński, Ustrój władz administracyjnych, rzadowych i samorzadowych, Poznań 1937.

Miasto. Pamięć i Przyszłość 3/2 (2018) ISSN 2543-621X 